\title{
"Training and Development as a Tool For Enhancing Employee's Productivity: A Case Study of Ashaka Cement Company, Nigeria Plc."
}

\author{
${ }^{1}$ Ibrahim Ahmed and ${ }^{2}$ Yemen Yohanna \\ ${ }^{1,2,}$ Department of Business Administration,Faculty of Arts and Social Sciences, Gombe State University, P.M.B \\ 127, Gombe, Gombe State, Nigeria.
}

\begin{abstract}
This research work is embarked upon to give practical knowledge of "Training and Development as a tool for enhancing employee's productivity: A Case study of Ashaka Cement company Plc." It aims at examining the instrumentality of training and development in enhancing employee productivity. A simple random sample was adopted in selecting 50 respondents from the company and responses obtained through interview and administration of questionnaires. The data was analysed using tables and percentages and found that training and employee productivity correlates positively, training is a necessity and tribalism, undue favouritism, Sectionalism, and costs of training are problems associated with training and development. Base on this, the researcher recommended that, Ashaka Cem. Plc should understand that training and employee productivity have a positive relationship. They should also see training and development as a necessity and also not to tolerate tribalism, undue favouritism, religious bias, sectionalism when selecting staff for training.
\end{abstract}

\section{Background Of The Study}

Training and development includes all attempts to improve productivity by increasing an employee's ability to perform (Nickells 2002). Therefore, training and development should be seen as a tool for enhancing employee's productivity. This is as rightly put by Hunter and Hunter, that among the identified personal factors, research shows that ability test scores correlate better than any other factor with job performance (Ogunbameru, 2004). This suggests that human resource department of any organisation should regularly assess and evaluate the training and development needs of their organisation for effective and efficient achievement of short, medium and long term objectives and goals of the organisation. This is because training and development makes an effective and efficient employee. Managers are therefore, advised to understand the correlation between training and employee productivity.

The history of training development was as old as the history of man on earth. It can be traced back to when people begin to achieve goals (targets) through group efforts in which those involved needs to be trained and developed for effective and efficient goal realization.

Frederick W. Taylor (1856-1915) whose basic ideas led to increased productivity and efficiency recognized the importance of training in his principles of management, that the best man to do the job must be scientifically selected and trained.

As history evolved, various training techniques and methods were used in various periods depending on the dynamism of the business environment especially the technological environment. But then, there was no full time training of employees. Full scale training of civil servants began in many Western countries in the decades after World War II. The most important development was perhaps the findings in 1945 of the National School of Administration in Paris. Which serves as both professional school and recruitment agency for the French government's administration and diplomatic services. Great Britain, India and other countries have developed their own civil servants. At the time, less-developed countries have unique problems of training, and therefore has to send their key personnel for training abroad.

Chandan (2007) asserts that, "In the past training and development was primarily oriented towards functional, chnical and specific job related skills, in today's business and managerial environment, the training and development programmes stressed a broad range of group interaction, skills, cross-functional issues, quality issues and diagnostic problem solving skills."

All the aforementioned trends in training and development techniques or methods are efforts towards making it (i.e training and development) an effective instrument for increased productivity. Unfortunately however, there are still those who feel that systematic training is costly or beyond their capabilities, while some hinders the effectiveness of training through corruption, tribalism and undue favouritism. Yet, most managers know that a person such as a secretary who is skilled in his job is more efficient than an unskilled person. It is in view of this that the importance of understanding training and development as a tool for enhancing employee productivity becomes necessary and hence the research work. 


\subsection{Statement Of Research Problems}

Training and development is the process of developing knowledge, skills and behaviours in people that will enable them to better perform their current and future jobs (Chandan, 2000). The aim of establishing any training and development programme by organisations, should therefore be with the expectation of enabling employees to better perform their current and future jobs for increased productivity.

Furthermore, the effectiveness of any training and development programme can be measured in terms of its contributions to the achievement of the overall objectives of the organisation. Such effectiveness can be approximated by a number of measures such as organizational production and the costs of operating that system. The instrumentality (or effectiveness) of training and development is though being recognised by most organisations; especially Ashaka Cement Plc because of their varied training and development programmes, but there still exist some problems such that if the cost of training is put into consideration, as training employees demand a lot of input financially from the organisation. Also the duration of training is one of the problems associated with it, as training can take much time depending on what the person knows and what he is supposed to know. When mangers or employers put into consideration such factors as these, training and development becomes a secondary thing for them. Moreover, sometimes even with good training and development programmes on ground, bedevilment of this generation such as corruption, tribalism and undue favouritism do comes in. In essence, all the above mentioned problems to a great extent hinders the effectiveness and efficiency of training and development programmes and affect organisational productivity adversely.

\section{$1.2 \quad$ Objectives Of The Study}

The general objective of this study is to examine and analyze the position and importance of training and development in enhancing employee's productivity in an organisation. While the specific objectives are:

i. To examine the correlation between training and employees' productivity in an organisation.

ii. To examine the necessity of an employees' training and development in an organisation.

iii. To investigate the types of problems associated with training and development of employees.

\subsection{Research Questions}

The study intends to answer the following questions:

i. What is the relationship between training and employee productivity in an organisation?

ii. Is it necessary for an organisation to train and develop their employees?

iii. What are the types of problems associated with training and development of employees?

\subsection{Conceptual Framework/Literature Review}

For the purpose of this study, the researcher is going to use certain terms/concepts which will help in guiding his research work such as training, development, and productivity.

Training can be defined as a process which is planned to facilitate learning so that people can become more effective in carrying out aspects of their work (Barau, 2008). Development usually means programmes that attempt to improve the technical, human relations and conceptual skills of managers (Barau, 2008). Productivity is a measured relationship between the quantity and quality of results produced and the quantity of resources required for production. Productivity is in essence, a measure of the work efficiency of an individual, work unit, or entire productivity (Hartzell, 2006).

Apart from this, various scholarly works will also be reviewed; to help in providing a base for the study.

\subsection{Research Methodology}

The researcher intends to use survey method.

\section{Sources of Data:}

Primary sources of data collection in which personal interview and questionnaire will be used and Secondary sources of data collection; in which textbooks, journals, newspapers and other similar sources will be used.

\subsection{Significance Of The Study}

The study will certainly create more awareness to organizations on the importance of training and development in enhancing organizational productivity. Furthermore, this work would give other researchers wishing to conduct research into training and development a framework for further research.

Moreover, the research experience will be of benefit to the researcher in that it will widen his knowledge on this topic and other fields of research generally.

\subsection{Scope And Limitations Of The Study}

The research will be conducted from May, 2013 to March 2014 and it intends to cover and limit itself 
to the examination and analysis of training and development as a tool for enhancing employees' productivity with Ashaka Cement Company Plc. as a case study. However, certain factors that pose limitations to the study such as finance will be the major constraint to this study which is involved in sourcing relevant materials, time and costs of transportation to Ashaka Cement factory.

Moreover, due to the increasing demand for cement in northern Nigeria in 1972, the federal government in its effort and concern for economic growth and development invited experts to carry out a feasibility study for establishing cement works at Ashaka. Results of the survey confirmed the potential viability of the first Cement works in the North-Eastern Zone of Nigeria.

Consequently, in 1974, Ashaka Cement Company was established as part of the initiative of the Nigerian Industrial Development Bank (NIDB), the Federal Government of Nigeria, the Nigerian Bank for Commerce and Industry (NBCI), the Northern Nigeria Investment, , limned and the North-Eastern Zone of Nigeria in collaboration with the Blue Circle Industry of UK.

The principal shareholders then were the Nigerian federal government, the government of the NorthEastern States and the Blue circle. Blue circle was the one given the responsibility of designing and building the new works and also participating as management partners.

In July, 2000, as a result of worldwide acquisition of Blue Circle industries plc. by Lafarge SA France; West African Portland Cement Plc. and Ashaka Cement Company became subsidiaries of Lafarge. The integration of WAPCO and Ashaka into Lafarge group was concluded in 2002.

Presently, the company has a shareholding structure of $50.16 \%$ by Lafarge France and $49.84 \%$ was owned by the Nigerian public under the privatization and commercialization policy of the Federal Government.

\section{Geographical Location Of Ashaka Works And Other Related Informations}

Location: The Ashaka Cement works is situated in Ashaka town which is $80 \mathrm{~km}$ north from Gombe town and $330 \mathrm{~km}$ south from Kano. It is on longitude $11^{\circ} \mathrm{E}$, and latitude $11^{\circ} \mathrm{N}$ in Funakaye local government area of the present Gombe State.

Drainage System: The area is drained principally by rivers and its tributaries which are dominated by a major drainage system and river Maza. This river raises through a number of faults controlled tributaries from the highlands employing into the north-south flowing river Gongila in the south-east of the state.

Topography: The terrain has a gentle gradient from the west of the factory site, a high relief and this form a very steep scarp as exemplified in the Gongila village map of the northern part of the factory. Approaching the North-South ward of Ashaka village, the gradient is very gentle. The Southward of the company is gentle undulating, but rising gently from about $280 \mathrm{~m}$ above the sea level in the South-Eastern part.

Climate: The climate of this area is typical of the Northern belt of Nigeria; with a mean annual rainfall of 75 $112 \mathrm{~cm}$; mean annual temperature of about $24-27^{\circ} \mathrm{C}$.

\subsection{An overview:}

\section{Literature Review}

The instrumentality of training and development can never be over emphasized. This is especially in today's business world that has increasing competitive business environment, climate change and other emerging global changes which ensure the continued dynamism and uncertainties enveloping the business world (Cole, 2004). In particular, the rapid contemporary advances in technological changes which made training a necessity in almost all works of life.

This accelerating rate of change and global competition has made training and development into an important personal, organizational and national issue (Jonathan, 2013). Training and development is now recognized as critical to competitive success which makes most organizations to be looking carefully at their human resources budget. With businesses needing to tighten their belt, one of the areas which ought to be considered indispensable is training and development. The success of every business depends on its staff and it has been found that people work most satisfactorily when they have confidence in their employer, their surrounding and particularly in the performance of their jobs. Obviously, a single factor contributes to creating this sense of confidence (Salvi, 2000). But possibly more than anything else, effective induction, i.e the introduction of everything surrounding a person's job, through training and skills necessary to do their jobs are responsible for creating the confidence which can lead to a person doing his job in a competent and satisfactory manner.

Training and development is seen as a process being done in a continuous basis and it is costly. Perhaps that is why some myopic employers are asking as to whether they can afford it. Instead, James (2009), suggest the right question as follows: "While many organizations may be asking the question, can we afford to spend on 
training and development? a more pertinent question would be, can we afford "not" to spend on training and development?

\subsection{Meaning And Definition Of Training And Development. Training:}

Training is an organized activity for increasing the knowledge and skills of people for a definite purpose (Salvi, 2000). It involves systematic procedures for transferring technical know-how to the employees so as to increase their knowledge and skills for doing specific jobs with proficiency.

Flippo, as cited in Chhabra, (2006), "training is the act of increasing the knowledge and skills of an employee for doing a particular job". It involves the development of skills that are usually necessary to perform a specific job. The purpose is to achieve a change in the behaviour of those trained and to enable them to do their jobs better. Training makes newly recruited workers fully productive within a short period of time. It is also important for the old employees whenever new machines and equipments are introduced and or there is a change in the techniques of doing things. In fact, training is a continuous process in which managers continuously engaged in training their employees to ensure positive changes in knowledge, skills and attitudes of the workers (Cole, 2004). The purpose of training is to bring about improvement in the performance of work. It includes learning of such techniques as are required for better performance of definite tasks.

Despite the fact that employee training has no universal accepted definition; its basic idea remains the same. Below are few scholarly definitions.

Barau (2008), training can be defined as a process, which is planned to facilitate learning so that people can become more effective in carrying out aspects of their work. Similarly, Byars, (2000), argued that, training is a learning process that involves the acquisition of skills, concepts, rules, or attitudes to enhance the performance of employees.

\section{Development:}

Management development consist of all activities by which managers learn to improve their behaviour and performance. It is designed to prepare them for higher jobs in the future.

Chhabra, Ahuja \& Jain as cited in Chhabra (2006), "management development is the process by which mangers acquire not only skills and competencies in their present jobs but also capabilities for future managerial tasks of increasing difficulty and scope". Thus management development is a planned, systematic and continuous process of learning and growth designed to induce behavioural change in individuals by cultivating their mental abilities and inherent qualities through the acquisition, understanding and use of new knowledge, insights and skills as they are needed for effective managing.

Development of managers takes place not only by participating in formal courses of instruction drawn by the organization, but also through actual job experience in the organization. It should be recognized that it is for the organization to provide development opportunities for its managers and other employees. But an equal, perhaps more important, counterpart to the efforts of the organization are those of the individuals. Selfdevelopment is an important concept in the whole program of management of development. The participants must have the capacity and motivation to learn and develop themselves.

\section{Training And Development}

Nickells, (2007), training and development includes all attempts to improve productivity by increasing an employee's ability to perform. While in the words of Chandan, (2007), training and development is the process of developing knowledge, skills and behaviours in people that will enable them to better perform their current and future jobs.

\subsection{Training And Development: What Is The Difference?}

Jayavel, K. has noticed the following differences between training and development:

1. Training is imparted to a person where it is needed; whereas development is a continuous process. A person if helped to learn on a particular technology, it is said to be training; whereas if a person is imparted on few aspects which might not be required directly to his profile but which influence his work like managerial skills is known as development.

2. Training is generally given to the operational level employees and development is done for middle level and top level executives.

3. Training need analysis is done to capture the training requirements of a resource; whereas development activities are based on the role of the employee.

4. Training focuses on short term needs whereas the development is highly focused on long term needs. For example, training is a sort of organised event whereas development takes place in a continuous basis. (eg job rotation). 
5. Training specifically focuses on making the employee learn about a new technology or new advancements in his routine process; whereas development is done for the enhancement of the personal qualities of an employee. In a nutshell, training is a narrow term; whereas development is a broad term.

\subsection{Education, Training, Development And Learning}

Some of the above mentioned terms especially learning and training are used interchangeably by some people; but they have their specific meanings in which knowing them will help in matching training and development objectives with the right program. Cole (2005), has given their specific meanings as below:

Education: Education will be taken to mean any long-term learning activity aimed at preparing individuals for a variety of roles in society. It relates to the basic instruction in knowledge and skills designed to enable people to make the most of life in general, it is personal and broadly based. Closely related to fulfilling organizational goals and objectives improving productivity and providing quality products and services. Long before any actual training occurs, the training manager must determine who, what, when, where, why and how of training by conducting needs assessment.

The need which is being assessed is generally described as a gap between what is currently in place and what is needed, now and in the future. Gaps can include difference between what the organisation expects to happen and what actually happens, current and desired job performance, existing and desired competencies and skills etc.

Once the needs assessment is completed and training objectives are clearly identified, the design phase of the training and development process is initiated, then implementation and evaluation.

\subsection{Needs Assessment}

Miller, (2002), there are three levels of needs assessment: organizational analysis, task analysis and individual analysis.

A) Organisational analysis: It looks at the effectiveness of the organisation and determines where training is needed and under what conditions it will be conducted.

The organisational analysis should be among others identify the state of the economy and the impact on operating cost, changing technology and automation, increasing world/global market. Political trends such as sexual harassment and work place violence.

B) Task analysis: This provides data about a job or a group of jobs and the knowledge, skills, attitudes and abilities needed to achieve optimum performance.

\subsection{Theories Of Learning}

Two major theories have dominated learning research over the years. One position is the cognitive view. Its proponent argues that an individual's purposes or intentions direct the individual's actions. The other position is the behavioural learning theory which is viewed as mechanistic or behaviourist because only observable behaviour is considered to represent learning Clatt et al (1985), has summarised this position as thus:

Thorndike's law of effect states that a strong stimulus-responses bond depends on the enforcer (reward or punishment following behaviour). Thus, behaviour depends upon its consequences. This leads to the concepts of acquisition of new behaviour and extinction of old behaviour.

More recently, an approach has been offered that blends both of these theories. That learning is a continuous interaction between the individual and the particular social environment in which the individual functions. This theory acknowledges that we can learn by observing what happens to other people and just by being told about something, as well as by direct experience since much of training is observational in nature, this theory would appear to have considerable application potential.

The influence of models is central to the social-learning view point. Research indicates that much of what we have learned comes from watching models such as parents, teachers, peers, motion pictures and television performers, bosses etc.

Social-learning theory offers us insight into what a training exercise should include. Specifically, it tells us that training should provide a model, it help the trainee's attention, provide motivational properties, help the trainee file away what has been learned for later use, and if the training has taken place off-the-job, allow the trainee some opportunity to transfer what has been learned to the job.

Basically, the social-learning model tell us that training should provide the trainee with a given model to follow, specific goals to achieve, an opportunity to perfect the skill, feedback on how well the trainee is progressing and praise for transferring the acquired skills to the job. These recommendations should guide the human resources manager in designing, implementing and operating any employee training. 


\subsection{Methods And Techniques Of Training}

On-the job training: this is most fundamental type of training. The employee being trained on the job immediately begins his or her tasks and learns by doing, or watches others for a while and then imitates them, right at the work place. Naturally this can be quite effective or disastrous, depending on the skills and habit of the person being watched. It is obvious the easiest kind of training, it minimizes the problems of transfers of learning and it does not disrupt normal company operation. The major disadvantage is that the trainee could pick up bad habits.

Apprenticeship programmes: in this system, a learner works alongside an experienced employee to master the skills and procedures of a craft. Sometimes, it involves classroom training. Many skill works such as plumbing, electrician, mechanics, etc, require apprenticeship training.

Vestibule training (near the job training): it is done in classrooms where employees are taught on equipment similar to that used on the job. The trainees are trained off their regular work area but in an environment closely resembling their workplace. Trainee practices with identical equipment that he/she uses at his/her regular workplace. They learn proper methods and safety procedures before assuming a specific job assignment in an organization.

Job rotation: this is a training device that make it necessary to move the trainee from one department or unit to another to master what goes on in that section. The essence is to broaden his experience in different jobs.

Employee orientation: is the activity that initiates new employees to the organisation to fellow employees, to their immediate supervisors and to the policies, practices, and objectives of the firm. Orientation programmes include everything from informal talks to formal activities that last a day or more and include schedule visits to various departments and require reading of hand books.

Online training: In this training method employees "attend" classes through the internet. Such programmes are sometime called distance learning because the trainees are separated by distance from the trainer or content source.

\subsection{Management Development}

The techniques developed for managerial development are designed to keep the management up-todate with the dynamic developments in the areas of technology and behavioural sciences. It can be either on-thejob or as given below by Chandan, (2007).

1. On-the-job methods. Usually preferred in management development programmes because it saves production hours and the programme can be more conveniently tailored to the individual. This training is achieved in any of the following ways.

i. Couching: in this techniques, the manager (trainer) and the subordinate trainee work together in a student- tutor relationship in which trainer couches and guides the trainee and the purpose is to explain the "whys" and "hows" of particular job functions, and provides feed back to the trainee regarding his performance and any grounds for improvements.

ii. Job rotation: this refers to the movement of trainee executives from one job to another within the trainee to be familiar with different aspects of outlook and exposure to a variety of management skills. It also enhances communication and flow of ideas among all divisions.

iii. Junior board meeting and committees: this method involves participation in junior board meeting and decision making committees where the information is shared and discussed involve real life organisational problems,. It helps the trainee in widening his perspective and he is initiated to the managerial processes of understanding, comprehension, analysis and decision making.

iv. Planned work activities: This involves giving trainees important work assignments to develop their experience and ability. Trainees may be asked to head a task force so that they can acquire leadership and managerial skills.

2. Off-the-job methods: Off-the-job training programmes are used outside the work setting. It could be done within the organisation at a separate training facility or at an offsite location such as training programmes sponsored by universities or professional organisations such as American Management Association. Some of the off-the- job training techniques are:

i. Class room lecture: a lecture simply means a teacher delivering lectures and explaining issues to a group of trainees in a classroom setting.

ii. Case studies: in this technique, an actual business situation is presented to the trainee in writing and in comprehensive manners. The trainee is asked to identify the problems in the case, analyze the situation and 
suggest solutions. These solutions are then compared to the actual solutions that were previously developed in solving such problems.

iii. Role playing: Includes people to assume the role of a specific individual under specific organisational conditions.

\subsection{Why Does Training Often Fail?}

Even in companies that tend to support the training of employees, and take training and development opportunities available to employees, much of the resources allocated to training are wasted. That is, there are no measureable or obvious positive results in terms of better employee contributions or productivity. The reason is that support for training is not enough. It must be planned and linked properly (Green, 2006).

If training and employee development are not "aimed at addressing needs and wants of both company and attendees, they are not likely to hit any worthwhile target. The result is an investment of time and money (Sharma, 2011)

Training that is correctly designed and conducted should greatly reduce the time needed for essential (unavoidable) learning. If the training methods are correct and properly and consequent saving that will, at the very least, recover the time and money wasted. The costs of a truly effective training should only be a small fraction of the value of resulting improvements in efficiency and productivity.

\subsection{Problems Associated With Management Development In Nigeria}

Nwachukwu (2007), the following are some of the problems associated with management development in Nigeria as indentified by organizations and employees:

i. The objectives of the training programme are not clearly stated to the participants. There is no mental preparedness.

ii. Some employees see some development programmes as a few days off work that are meant for relaxation.

iii. There is not positive reinforcement after the training.

iv. Most companies do not evaluate the outcome of the programmes. There are in many instances no examinations (either written or oral) or feedback.

v. The employee does not have the opportunity to put what he has learnt into practice.

vi. Many management development programmes are not properly planned and there are no sequences to the courses offered from year to year.

vii. There is the problem of transfer of learning. Some of the concepts and principles taught are very difficult to apply.

\section{Research Methodology}

Survey research method which is very important for both explanatory and descriptive studies is used in this study. This research is based on the findings of famous personalities who means to prove that training leads to better performance and is one of most important tool or factor that leads to higher confidence in return.

\subsection{Population Of The Study}

The target population for this research work is the entire staff of Ashaka Cement Plc in Gombe State, Nigeria. Presently, the entire population of staff in the industry is about 650 in which 50 employees were sampled for the study.

\subsection{Sampling Size And Techniques}

The researcher has taken a sample size of 50 out of the entire population for his investigation. The rationale behind it is particularly, that convenience sampling helps the researcher to be feasible in terms of finance and time, from the reduced population and hence good inference since he may find it difficult to handle the whole population.

\subsection{Instrument Of Data Collection}

The instrument used for collecting the data was was structured questionnaire.

\section{Sources Of Data Collection}

Two sources were used: A. Primary sources of data collection. First hand data (information) for this research work was collected using questionnaire and personal interview. The researcher was careful enough to obtain his data only from the population of this study.

B: Secondary source of data collection: Data was also collected from text books, journals, News-papers and other similar sources. 


\subsection{Data Analysis And Presentation}

The data collected or obtained through the questionnaire distributed were analyzed, summarised and interpreted using tables and percentage to present, analyze and summarize the data that we collected from the employees of Ashaka Cement Plc through administration of questionnaires after which the result was used to answer the questions. The aim is to find out empirically, the instrumentality of training and development in enhancing employee's productivity.

Table 1: Effect training and development on productivity.

\begin{tabular}{|l|l|l|}
\hline Responses & No. Of respondents & Percentage (\%) \\
\hline It decreases & 1 & 2.86 \\
\hline It increases & 34 & 97.14 \\
\hline Total & 35 & 100.00 \\
\hline
\end{tabular}

Source: Field Survey, (2014); Ashaka Cem. Plc.

Analysis: Table 4.8 above show that 1 respondent representing 3\% responded that training and development decreases productivity; while 34 respondents representing $97 \%$ are of the view that it increases productivity. This shows that training and development increases productivity and it is a commonly held view among the staff.

Table 2: Relationship between training and employee productivity.

\begin{tabular}{|l|l|l|}
\hline Responses & No. Of respondents & Percentage (\%) \\
\hline Positive & 33 & 94.29 \\
\hline Negative & 1 & 2.86 \\
\hline Undecided & 1 & 2.86 \\
\hline Total & 35 & 100.00 \\
\hline
\end{tabular}

Source: Field Survey, (2014); Ashaka Cem. Plc.

Analysis: table 4.10 above indicate that 33 employees of Ashaka representing 94\% responded that the relationship that exists between training and employee productivity is positive and an employee representing $3 \%$ also did not respond accordingly.

Table 3: Comment on the Company's Training Policies and Programmes.

\begin{tabular}{|l|l|l|}
\hline Responses & No. Of respondents & Percentage (\%) \\
\hline Excellent & 10 & 28.57 \\
\hline Good & 13 & 37.14 \\
\hline Fair & 11 & 31.43 \\
\hline Bad & 0 & 0.00 \\
\hline Undecided & 1 & 2.86 \\
\hline Total & 35 & 100.00 \\
\hline
\end{tabular}

Source: Field Survey, (2014); Ashaka Cem. Plc.

Analysis: Table 4.12 above shows that 10 respondents representing 29\% and 13 respondents representing 37\% comment that the company's training and development policies are excellent and good respectively; while 11 respondents representing 31\% comment that they are fair; none responded that it is bad and one representing 3\% did not respond. Based on this result, we can conclude that Ashaka cement has good training and development policies and programmes. 
Training and Development as a Tool For Enhancing Employee's Productivity” A Case Study ....

Table 4: Training and development in Ashaka Cement Company Plc

\begin{tabular}{|l|l|l|}
\hline Responses & No. Of respondents & Percentage (\%) \\
\hline Frequently & 6 & 17.14 \\
\hline Occasionally & 27 & 77.14 \\
\hline Not at all & 1 & 2.86 \\
\hline Undecided & 1 & 2.86 \\
\hline Total & 35 & 100.00 \\
\hline
\end{tabular}

Source: Field Survey, (2014); Ashaka Cem. Plc.

Analysis: Table 4.13 above shows that 6 respondents representing 17\% responded that the company use to send its staff for training and development frequently. 27 respondents representing $77 \%$ agreed that the company sends their staff for training and development occasionally, while one respondent is of the view that the company is not sending at all; and one did not respond.

Table 5: Necessity of employee training and development in Ashaka Cement Company Plc.

\begin{tabular}{|l|l|l|}
\hline Responses & No. Of respondents & Percentage (\%) \\
\hline Yes & 34 & 97.14 \\
\hline No & 1 & 2.86 \\
\hline Total & 35 & 100.00 \\
\hline
\end{tabular}

Source: Field Survey, (2014): Ashaka Cem. Plc.

Analysis: from table 4.14, 34 respondents representing 97\% opined that training and development is necessary in the company, while 1 respondent representing $3 \%$ responded that training is not necessary. This implies that training and development in the organisation is necessary.

Table 6: Effect of Cost on training and development.

\begin{tabular}{|l|l|l|}
\hline Responses & No. Of respondents & Percentage (\%) \\
\hline Yes & 14 & 40.00 \\
\hline No & 21 & 60.00 \\
\hline Total & 35 & 100.00 \\
\hline
\end{tabular}

Source: Field Survey, (2014): Ashaka Cem. Plc.

Analysis: Table 4.15 above shows that 14 respondents representing $40 \%$ are of the view that cost of training may reduce the level of training activity in Ashaka Cement company, while 21 respondents representing $60 \%$ are of the view that cost of training not reduce the level of training and development in Ashaka. Base on this result; cost of training and development any not reduce the level of training and development in Ashaka Cement Company. Three respondents representing $9 \%$ mention cost of training as problems associated with training and development in Ashaka Cement Company, which a little bit contradicts this result.

\section{Summary}

Central to this project work is to advance the frontiers of knowledge empirically on, "training and development as a tool for enhancing employee's productivity; with Ashaka Cement Plc as case study".

Therefore, with respect to this research work, the researcher found that the idea of training and development is common to almost all employees. Most of the workers in Ashaka Cem. Plc have received training and that there is a positive relationship between training and employee productivity. However, it is 
occasionally that Ashaka Cem. Plc sends its staff for training development, we discovered that training and development is necessary. Problems associated with training and development are tribalism, interest (subjectivity), religious bias, high cost of training, undue favouritism, corruption, poor management policies, failure to evaluate and receive training feedback, etc.

\section{Conclusions}

Base on the findings of this research, we acknowledged the importance of training and development, the need to make efforts in planning, training and development, policies and programmes considering that a positive relationship exist between training and employee productivity. But yet, problems and challenges exists which hinder the effectiveness of training and development.

\section{Recommendations}

In the first place, Ashaka Cement Plc and other organizations in general, should understand that training and employee productivity has a positive relationship. Organisations should have a well established training and development policies and programme and see training and development as necessary. Thus, managers should provide training and development opportunities for their workers.

Moreover, organisations should evaluate and receive feedback and shun tribalism, undue favouritism, religious bias and sectionalism among others for not only the betterment of employees themselves but the entire organisation

\section{References}

[1]. Barau, S. H. (2008), "Management: A simple practical Approach". $2^{\text {nd }}$ ed., Odenic Press: Jos Nigeria

[2]. Bittel, L. R. (1995), "Encyclopaedia of Professional Management". $2^{\text {nd }}$ ed. Vol.1. McGraw-Hill Inc: USA.

[3]. Byars, L. L. and Rue, L.W. (2000). "Human Resource Management, $6^{\text {th }}$ ed., McGraw Hill: USA

[4]. Chandan, J. S. (2007). "Management: Concepts and Strategies". Vikas Publishing House Ltd: New Delhi.

[5]. Chhabra, T. N. (2006). "Human Resource Management \& Issues". $5^{\text {th }}$ ed., Gagan Kapur Ltd: New Delhi.

[6]. Clatt, A. L. et al (1985). "Human Resource Management" Charles Emerrill Publishing company: Columbus Ohio.

[7]. Cole, G. (2005). "Management Theory and Practice". $2^{\text {nd }}$ edi. Book Power London.

[8]. James, M. (2009). "The advantages of Training and Development in the Workplace". Retrieved March 18th 2010 from htt://ezinearticles.com/?the-advantages of Training-and-development-in-the-workplace\&id+244587.

[9]. Jayavel, K. Retrieved March 18th, 2010 from http://www.citehr.com/141210-difference-between training-development. Html.

[10]. Maxwel, J. Retrieved March 18th, 2010 from http://winatworkzone.com/blog/training-and-development-what-is-the-difference/

[11]. Miller, J. A. and Osinski (2002), Retrieved March $18^{\text {th, }}$ 2010, from internet.

[12]. Nickels, W .F. et. al. (2002). "Understanding Business". McGraw-Hill: America.

[13]. Nwachukwu C. C. (2007). "Management Theory and Practice", Revised ed. Africana First Publishers Ltd: Onisha, Nigeria

[14]. Nwachukwu, C. C. (1992). "Management Theory and Practice", Africana First Publishers Ltd: Onitsha Nigeria.

[15]. Ogunbameru, O. A. (2004). “Organisational Dynamics” Spectrum Books Ltd: Ibadan, Nigeria.

[16]. Robins, S. P. et al. (1986). "Managing Human Resources" Printice Hall, Australia. 